Uşak Üniversitesi Sosyal Bilimler Dergisi

$2016,9 / 1$

\title{
Eğitim Yönetimi Denetimi Planlaması ve Ekonomisi Lisansüstü Öğrencilerinin Aldıkları Eğitim Hakkındaki Görüssleri*
}

Ümit KAHRAMAN ${ }^{* * *}$

Türkay N. TOK ${ }^{* * *+}$

Öz

Bu çalışma, Pamukkale Üniversitesi Eğitim Yönetimi Denetimi Planlaması ve Ekonomisi (EYDPE) alanında lisansüstü eğitim gören öğrencilerin, lisansüstü eğitim yapma nedenleri, eğitimden beklentileri ve bu eğitimin daha ileriye taşınabilmesi için getirdikleri önerileri ortaya koymayı amaçlamaktadır. Araştırma verileri lisansüstü eğitim alan 26 yönetici ve öğretmenin görüşlerinden elde edilmiştir. Nitel araştırma modelinin kullanıldığı araştırmada veriler içerik analizi tekniğiyle incelenmiştir. Araştırmanın sonucuna göre, lisansüstü eğitim alan öğrencilerin büyük çoğunluğu kendini geliştirmek ve kariyer yapmak amacıyla eğitime başlamıştır. Ayrıca öğrenciler lisansüstü eğitimin bilgi ve becerilerini artırması beklentisi içindedirler ve çoğunlukla bu beklentilerinin karşılandığını düşünmektedirler. Lisansüstü eğitim alan öğrenciler aldıkları eğitimin daha ileriye taşınabilmesi için eğitimlerin daha çok pratiğe yönelik olması, akademisyenlerin öğrencilere rehberlik yapması ve danışman öğretim üyelerinin daha ilgili olmasını önermişlerdir.

Anahtar Kelimeler: Lisansüstü Eğitim, Amaç, Beklenti

\section{Education Management Supervision Planning and Economics Graduate Students' Opinions about the Education They Receive}

\section{Abstract}

This study aims to introduce Pamukkale University post graduate students' reason of studying in post graduate, their expectations from this

\footnotetext{
* Bu çalışma EYEDDER (Eğitim Yöneticileri ve Eğitim Deneticileri Derneği) ve Gaziantep Üniversitesi tarafından 7-9 Mayıs 2015 tarihlerinde düzenlenen 10. Ulusal Eğitim Yönetimi Kongresi'nde sözlü bildiri olarak sunulmuş, genişletilerek makale haline getirilmiştir.

** Öğretmen, Uşak İl Milli Eğitim Müdürlüğü, ukahraman@meb.gov.tr

**** Doç. Dr., Pamukkale Üniversitesi, Eğitim Fakültesi, Eğitim Bilimleri

Bölümü, Eğitim Yönetimi Denetimi Planlaması ve Ekonomisi A.B.D.
} 
education and their suggestions to improve this education. The research data has been collected from 26 post graduate students who are directors or teachers. The data in this research for which quantitive analysis model was used was examined by content analysis. According to the results, most of the postgraduate students have started this education in order to improve themselves and to have a career. Also, students are in the expectation of the post graduate education's improving their qualities and skills and mostly they think that this expectation is fulfilled. The postgraduate students have suggested that in order to improve the education quality the training should include more practise, the academicians should guide the students and the consultants should be more concerned.

Keywords: Post Graduate Education, Aim, Expectation

\section{Giriş}

İçinde bulunduğumuz çağın bilgi çağı olarak nitelendirilmesi ve her bilimsel alanda olduğu gibi eğitim bilimler ve özelinde eğitim yönetimi alanında da yeni bilgilerin üretilmesi sonucunda, eğitimin, öğretmenlerin ve yöneticilerin nitelikleri sorgulanmaya başlamıştır. Sevinç (2001), toplumun ihtiyaç duyduğu nitelikli insan gücünün yetiştirilmesinde lisansüstü eğitimin önemli bir yere sahip olduğunu belirtmiştir. Lisansüstü eğitim, yüksek lisans ve doktora derecelerini kapsayan, kişilerin kendi alanlarında ya da diğer başka alanlarda uzmanlaşmalarını sağlayan, bilim insanı ve akademisyen yetiştirmeyi amaçlayan eğitim programlarıdır. Bilgiye sahip olmanın önemi ve toplumların ve insanların sürekli bir rekabet içinde olması eğitimin önemini artırmaktadır. Bu nedenle bazı öğretmenler sadece lisans diplomasına sahip olmayı kendileri için yeterli bulmadığından, bazı öğretmenler de Milli Eğitim Bakanlığı bünyesinde çalışmaktan memnun olmayıp, akademisyen olmak için lisansüstü eğitim almaktadırlar. Bu nedenle lisansüstü eğitime yönelik talep son ylllarda artma eğilimine girmiştir. Lisansüstü eğitime önem verilmesini etkileyen faktörler (Karakütük, 2002) aşağıda sunulmuştur:

- Ülke kalkınmasında yüksek nitelikli insan gücüne daha fazla ihtiyaç duyulması.

- İlköğretim süresinin uzaması ve çağ nüfusuna yaygınlaşması, ortaöğretimde de okullaşma oranının artmasına bağlı olarak yükseköğrenime gösterilen ilginin artması. 
- Bilgi birikimi ve teknolojik gelişmelerin hızlı gerçekleşmesi nedeniyle, yükseköğretimde kazanılan yeterliliklerin mezun olduktan sonra yeterli olmaması ve mezun olduktan sonra da eğitimi gerekli kılması.

- İşverenlerin diplomaya ücret ödemesi ve lisansüstü eğitim yapmış kişilerin piyasada aranması.

Genel olarak lisansüstü eğitim, lisansüstü derecelere götüren araştırma yoluyla bilgiye katkıda bulunacak, gelişen toplumun ihtiyacını karşılayacak bilim insanı ve öğretim elemanı yetiştirmeyi amaçlayan bir eğitim faaliyetidir. Lisansüstü eğitimin içinde yer alan yüksek lisansın amacl, alanında uzmanlaşmış bireyler yetiştirmek, doktora eğitimine temel oluşturmak ve bireylere bilimsel süreci kavratmaktır. Ayrıca ülkenin iş gücü ihtiyacına yönelik eleman yetiştirmek üzere akademik ve mesleki çabaları kaynaştırmak da yüksek lisansın amaçlarından birisidir (Varış, 1972). Yüksek lisans programından mezun olan kişiler İngilizcede "master" Türkçede ise "uzman" sıfatını kazanırlar (Arı, Pehlivanlar ve Çömek, 2012). Doktora, lisansüstü eğitimin son basamağıdır. Yüksek lisans eğitimini tamamlayan kişiler gerekli şartları sağladıklarında doktora programına kabul edilirler. Ders ve tez aşaması olarak iki bölümden oluşan bu eğitimi başarıyla tamamlayanlara "Doktor" unvanı verilir (Başaran, 1996; Akt. Arı, Pehlivanlar ve Çömek, 2012). Doktora eğitiminin amacı ise, ekonomik ve teknolojik kalkınma için gerekli temel araştırmaları planlayıp, yürütecek, sonuçlandıracak ve yayımlayacak bilim insanı, öğretim üyesi ve araştırmacı yetiştirmektir (Varış, 1972).

Bu araştırmanın yapıldığı Pamukkale Üniversitesi (PAÜ)'nin yüksek lisans programı; en az dört yıl süreli bir yükseköğretim kurumundan lisans diploması ya da buna eşdeğer bir derece almış olanların, bu eğitim üzerine yapacakları dört yarıyıl süreli öğretim, bilimsel araştırma, sanatsal tez ve uygulama etkinliklerini kapsar. Tezli yüksek lisans programı için, azami öğrenim süresi altı yarıyıldan oluşan üç yıldır. En az iki yarıyılı tez süresi olmak üzere yüksek lisans programı en erken üç yarıyılda tamamlanabilir. Tezsiz yüksek lisans programını tamamlama süresi en fazla altı yarıyıldır. Derslerini ve dönem projesini başarı ile tamamlamış ve akademik ortalaması en az 3.00 olan öğrenciler daha kısa sürede mezun olabilir.

Doktora programı ise; yüksek lisansa dayalı sekiz, lisansa dayalı on yarıyıllık öğretim, yeterlik sınavı, tez önerisi ve tez çalışmasından oluşur ve öğrenciye bağımsız araştırma yapma, bilimsel olayları geniş ve derin bir bakış açısı ile irdeleyerek yorum yapma ve yeni sentezlere ulaşmak için gerekli adımları belirleme yeteneğini kazandırmayı amaçlar. Doktora programını tamamlama süresi tezli yüksek lisans derecesi ile kabul edilenler için azami on iki yarıyıl, lisans derecesi ile kabul edilenler için azami on 
sekiz yarıyıldır. En az dört yarıyılı tez süresi olmak üzere doktora programı en erken altı yarıyılda tamamlanabilir. Öğrenim süresi sonunda mezuniyet için akademik ortalamanın en az 3.30 olması, seminer dersi ve tez çalışmasının başarıyla tamamlanması gerekir (PAÜ Lisansüstü Eğitim ve Öğretim Yönetmeliği, 2013).

\section{Araştırmanın Amacı ve Önemi}

Eğitimde, en çok tartı̧̧lan konulardan birisi öğretmen ve yönetici yeterlikleridir. $\mathrm{Bu}$ konu akademisyenler tarafından incelenmekte, milli eğitim şûralarında da gündeme gelmektedir. Okul yöneticilerinin ve öğretmenlerin kendilerini yetiştirebilmeleri açısından EYDPE (Eğitim Yönetimi, Denetimi, Planlaması ve Ekonomisi) alanında lisansüstü eğitim almaları önemlidir. Eğitim kurumlarının nitelikli olabilmesi için nitelikli kişiler tarafından yönetilmesi gerekir. Arı, Pehlivanlar ve Çömek (2005), nitelikli insan gücünün ancak yükseköğretim kurumlarında yaratılacak iyi bir öğretim ve araştırma ortamı sayesinde yetiştirilebileceğini belirtmişlerdir. Bu sebeple yükseköğretim kurumlarında verilen lisansüstü eğitimin niteliği, nitelikli yönetici ve akademisyen yetiştirilmesi açısından çok önemlidir. Lisansüstü eğitimin niteliği, üniversitenin niteliğini, üniversitenin niteliği ise toplumun niteliğini etkilemektedir (Alhas, 2006). Bu çalışmada, PAÜ EYDPE alanında eğitim alan lisansüstü öğrencilerin eğitimin geliştirilmesine yönelik görüşleri alınarak, eğitimin nasıl olması gerektiğine cevap aranmıştır.

Ayrıca 06/10/2015 tarih ve 29494 sayılı Resmi Gazete' de yayınlanan “Milli Eğitim Bakanlığı Eğitim Kurumları Yöneticilerinin Görevlendirmelerine Dair Yönetmelik" ile eğitim kurumlarında görevlendirilecek müdür değerlendirme formunda eğitim yönetimi alanında lisansüstü eğitim alan öğretmenlere ek puan vermektedir. Bu yönetmeliğe göre, eğitim kurumu müdür olarak ilk defa ve yeniden görevlendirileceklere ilişkin değerlendirme formunda yönetim alanında yüksek lisans yapanlara 5, doktora yapanlara 10 ek puan verilmektedir (Millî Eğitim Bakanlığı'na Bağlı Eğitim Kurumları Yöneticilerinin Görevlendirilmelerine Dair Yönetmelik, 2015). Bu kapsamda bu araştırmanın problemi, "Pamukkale Üniversitesi EYDPE Bilim Dalı'nda eğitim gören öğrencilerin lisansüstü eğitim hakkındaki görüşleri nelerdir?" olarak belirlenmiştir.

Lisansüstü eğitim hakkında son zamanlarda yapılan çalışmalarda artış gözlenmektedir. Ünal ve İlter (2010) karma araştırma deseninde yapmış oldukları çalışmada, sınıf öğretmeni adaylarının lisansüstü eğitime yönelik tutumlarını ortaya koymuş, Ören, Yılmaz ve Güçlü (2012), öğretmen 
adaylarının lisansüstü eğitime ilişkin görüşlerinin alındığı nitel bir çalışma yapmışlardır. Arı, Pehlivanlar ve Çömek (2005) tarafından, lisansüstü eğitim gören öğrencilerin lisansüstü eğitime başlamadan önce ve başladıktan sonraki beklenti ve düşünceleri hakkında nicel bir araştırma yapılmıştır. Kaya, Sezgin ve Kavcar (2005) araştırmalarında, eğitim bilimleri enstitüsünde verilen lisansüstü eğitim hakkında öğrenci ve öğretim üyelerinin değerlendirmelerine yer vermişlerdir. Savaş ve Topak (2005), lisansüstü öğrenim gören öğrencilerin beklentileri ve lisansüstü öğrenimi talep etme gerekçelerini araştırmışlardır. Oluk ve Çolak (2005), Milli Eğitim Bakanlığı'na bağlı okullarda öğretmen olarak çalışan ve aynı zamanda lisansüstü eğitimine de devam eden öğretmenlerin, lisansüstü eğitimleri süresince karşılaştıkları bazı sorunları, yönetmelik, ekonomik katkı ve eğitim-öğretim açısından incelemişlerdir. Başer, Günhan ve Yavuz (2005), ortaöğretim fen ve matematik alanında öğrenim gören tezsiz yüksek lisans öğrencilerinin aldıkları eğitimden beklentileri, yaşadıkları sorunlar ve çözüm önerileri üzerine bir çalışma yapmışlardır.

Bu çalışma sadece bir alana yönelik olması sebebiyle diğerlerinden ayrılmaktadır. Lisansüstü eğitim hakkında yapılan çalışmalarda genellikle beklenti ve amaçlar, aynı kavramlar olarak kullanılmıştır. Bu çalışmada ise, lisansüstü eğitime başlamadaki amaçlar ve eğitimden beklentiler ayrı ayrı işlenmiştir. Lisansüstü eğitim alan öğrencilerin beklenti durumları, daha çok üniversiteden ve bölümlerinden beklentileri şeklinde yorumlanmıştır. $\mathrm{Bu}$ çalışmanın başka bölümler ve üniversitelerde de yapılması ile aradaki farklılıkları yorumlamak daha kolay olacak ve karşılaştırma firsatı doğacaktır. Türkiye'de son zamanlarda lisansüstü eğitim hakkında çalışma sayıları artmış olsa da, en çok çalışılan alan tezsiz yüksek lisans öğrencileri olmuştur. Tezsiz-tezli yüksek lisans ve doktora öğrencilerinin tümünü kapsayan çalışma sayısı yeterli değildir. Bu çalışma ile alandaki boşluğu doldurmak amaçlanmıştır.

Bu çalışmanın amacı, EYDPE Bilim Dalı'nda lisansüstü eğitim alan öğrencilerin lisansüstü eğitim yapmalarındaki amaçlarını, lisansüstü eğitimden beklentilerini ve EYDPE Lisansüstü Programı'nın geliştirilmesi için getirdikleri önerileri ortaya koymaktır. Bu bağlamda aşağıdaki sorulara cevap aranmıştır:

1. EYDPE Bilim Dalı'nda lisansüstü eğitim alan öğrencilerin lisansüstü eğitim almadaki amaçları nelerdir?

2. EYDPE Bilim Dalı'nda lisansüstü eğitim alan öğrencilerin lisansüstü eğitimden beklentileri nelerdir?

3. EYDPE Bilim Dalı'nda lisansüstü eğitim alan öğrencilerin beklentileri nelerdir ve ne düzeyde karşılanmıştır? 
4. EYDPE Bilim Dalı'nda lisansüstü eğitim alan öğrencilerin lisansüstü eğitimin geliştirilmesine yönelik önerileri nelerdir? Bu öneriler programa ve göreve göre değişmekte midir?

\section{Araştırmanın Yöntemi}

EYDPE lisansüstü eğitim hakkında öğrenci görüşlerini inceleyen bu araştırma nitel bir özel durum çalışmasıdır. Nitel özel durum çalışmaları eğitimde çeşitli konuları anlamada kullanılan bir araştırma yöntemidir (Ekiz, 2009). Araştırmada tarama modeli kullanılmıştır. Nitel araştırmalarda veri toplama yöntemlerinden birisi de ankettir. Anket, araştırma katılımclarının doldurduğu veri toplama aracıdır. Genellikle kağıt kalem kullanılmaktadır ancak giderek internet üzerinden de katılımclara sunulmaktadır. Anketler kapalı uçlu sorulardan oluşabildikleri gibi açık uçlu sorulardan da meydana gelebilir (Christensen, Johnson, Turner, 2015).

\section{Çalışma Grubu}

Araştırma katılımcıları, Pamukkale Üniversitesi Eğitim Bilimleri Enstitüsü EYDPE Bilim Dalı'nda tezsiz yüksek lisans, tezli yüksek lisans ve doktora programlarında lisansüstü eğitim alan 26 öğrenciden oluşmaktadır. Örneklem seçiminde amaçlı örnekleme yöntemlerinden kolay ulaşılabilir durum örneklemesi yöntemi kullanılmıştır. Bu örnekleme yöntemi araştırmaya hız ve pratiklik kazandırır (Yıldırım ve Şimşek, 2011)Soru formunda çalışma grubundan isim yazmamaları istenmiştir. Araştırmada görüşlere yer verilirken her bir katılımcı eğitim düzeyine göre kodlanmıştır. Örneğin TL1 tezli yüksek lisans grubundaki birinci katılımc1, TS1 tezsiz yüksek lisans grubundaki birinci katılımcı ve D1 doktora grubundaki birinci katılımcıyı ifade etmektedir. Çalışma grubuna ait bilgiler Tablo 1'de yer almaktadır.

Tablo 1. Çalışma grubuna ait program ve görev bilgileri

\begin{tabular}{clccc}
\hline & & N & Frekans (\%) \\
\hline \multirow{4}{*}{ Program } & Tezsiz Y.L. & 6 & 23,08 \\
\cline { 2 - 4 } & Tezli Y.L. & 14 & 53,84 \\
\cline { 2 - 4 } & Doktora & 6 & 23,08 \\
\hline \multirow{3}{*}{ Görev } & Öğretmen & 19 & 73,08 \\
\cline { 2 - 4 } & Okul Yöneticisi & 4 & 15,38 \\
\cline { 2 - 4 } & Müfettiş & 0 & 0 \\
\cline { 2 - 4 } & Dĭğer & 3 & 11,54 \\
\cline { 2 - 3 } & & &
\end{tabular}




\section{Veri Toplama Aracı ve Analizi}

Araştırma verilerinin toplanması için uzman görüşlerine başvurularak hazırlanan açk uçlu dört sorudan oluşan soru formu, katılımcıların e-posta adreslerine yollanmıştır. Katılımcılardan gelen formlar araştırmacılar tarafından incelenmiş, soru ile cevaplar arasında uyumsuzluk olanlar değerlendirmeye alınmamıştır. E-posta yoluyla toplanan veriler tablo haline getirilerek içerik analizine tabi tutulmuştur. İçerik analizinde temel amaç, betimsel analizde özetlenen verilerin daha derinlemesine bir işlemden geçirilerek, betimsel analizde fark edilemeyen kavram ve temaların keşfedilmesini sağlamaktır. Bu amaçla öncelikle veriler kavramsallaştırılır, daha sonra da ortaya çıkan kavramlara göre temalar belirlenir. Temelde yapılan işlem, birbirine benzeyen verileri belirli kavramlar ve temalar çerçevesinde bir araya getirmek ve bunları okuyucunun anlayacağı şekilde düzenleyerek yorumlamaktır (Yıldırım ve Şimşek, 2011).

\section{Bulgular}

\section{Lisansüstü Eğitime Başlama Amacına İlişkin Bulgular}

Lisansüstü eğitim alan öğrencilere gönderilen formun ilk sorusunda lisansüstü eğitime başlama amaçları sorulmuştur. Elde edilen verilerin analizi sonucunda ortaya çıkan temalar Tablo 2' de verilmiştir.

Tablo 2. Lisansüstü eğitime başlama amacı

\begin{tabular}{lll}
\hline Tema $\mathbf{( N = 2 6 )}$ & Frekans (f) & Oran $\mathbf{( \% )}$ \\
\hline Kendini geliştirmek & 18 & 37,5 \\
\hline Akademik kariyer & 11 & 22,9 \\
\hline Milli eğitim sisteminde kariyer & 10 & 20,8 \\
\hline Bilimsel çalışmalar yapmak & 6 & 12,5 \\
\hline Derece-kademe almak & 1 & 2,1 \\
\hline Maddi kazanç sağlamak & 1 & 2,1 \\
\hline Fark yaratmak & 1 & 2,1 \\
\hline
\end{tabular}

Tablo incelendiğinde, lisansüstü eğitime başlamadaki amaçların yedi yedi tema altında toplandığı görülmektedir. Katılımcılar en çok, kendilerini geliştirmek ( $\mathrm{f}=18, \% 37,5)$ için lisansüstü eğitime başladıklarını belirtmişlerdir. Bu tema kendini yenilemek, donanımlı bir öğretmen olmak, yeni sistemlere ayak uydurmak gibi kavramları içermektedir. Lisansüstü eğitim alan öğrenciler lisansüstü eğitime kendilerini geliştirmek için başladıklarını şu şekilde ifade etmişlerdir: 
"Lisansüstü eğitime başlarken yöneticilik alanında yetkinliklerimi ve vasıflarm artırarak bu alanda görev aldığımda....." (TL13).

"Monotonlaşmış bir çalışma ortamında eksik bıraktığım ve yapmadığım uygulamaların farkına varmak; kendimi yenilemek için" (TS5).

"Mesleğimde durağan olmak istemiyorum. Ufkumu genişletmek, mesleğimde yenilikleri takip etmek, mesleki tecrübemi artırmak amacıyla lisansüstü eğitime başladım" (D3).

Bazı öğrenciler akademik kariyer yapmak ( $\mathrm{f}=11, \% 22,9)$ amacıyla lisansüstü eğitime başladıklarını belirtmişlerdir. Akademik kariyer yapmak amacıyla lisansüstü eğitim aldıklarını şu sözlerle ifade etmişlerdir:

"..... bu eğitimi almak istememdeki öncelikli amactm üniversitede kalmak ve iyi bir öğretim üyesi olmak diyebilirim" (TL6).

“...... akademik görev almak isterim"(TS6).

"...... Şu anda amactm eğitimimi başarılı bir şekilde devam ettirmek ve akademisyenliğe geçiş yapmak" (D5).

Milli Eğitimde Bakanlığı bünyesinde okul yöneticisi ve müfettiş olmak isteyen ( $\mathrm{f}=10, \% 20,8)$ lisansüstü öğrencilerinin görüşleri şunlardır:

“... hedefim ise öğretmenlik yillarındaki tecrübelerim ve lisansüstü eğitimde aldığım eğitimi birleştirerek bir eğitim kurumunda yönetici olmak" (TL14).

“Uzun süre öğretmenlik yapmayı düşünmüyorum. Denetmen olmayı istiyorum. Yüksek lisans bunun için bir ön hazırlk olarak görüyorum" (TS3).

"....... iyi bir eğitim yöneticisi ..... olmak" (D6).

Elde edilen verilerde "işini bilimsel yapmak" ( $\mathrm{f}=6, \% 12,5)$, dikkat çeken bir cevap olmuştur. Yaptığı işi bilimsel olarak yapmak isteyen lisansüstü öğrencilerinin verdiği cevaplardan bazıları şunlardır:

“..... eğitim alanında karşılaşı̆ğım sorunlara bilimsel çözümler üretebilmek" (TL1).

"...... olaylara farkh açılardan bilimsel bir şekilde bakabilme alışkanlığı kazanmaktır" (TL4).

“..... Yöneticiliğimi bilimsel olarak yapma arzum” (TS2).

Ayrica "derece-kademe almak" ( $\mathrm{f}=1, \% 2,1)$, "maddi kazanç sağlamak" (f=1, \%2,1) ve "fark yaratmak" ( $\mathrm{f}=1, \% 2,1)$ öğrencilerin lisansüstü eğitimdeki amaçlarındandır. Bunları aşağıdaki şekilde ifade etmişlerdir:

"..... belge, kademe ve derece için ......" (TL3). 
"Kariyer, maddi imkan $"(D 2)$

“..... en az 10 yillı deneyimi olan sinıf öğretmenlerinin arasında fark yaratan ilk ve tek kişi (tezli yüksek lisans yapan) olmayı istedim" (TL13).

\section{Lisansüstü Eğitimden Beklentilere İlişkin Bulgular}

Lisansüstü eğitim alan öğrencilerin aldıkları eğitimden beklentilerine ait temalar Tablo 3'te gösterilmiştir.

Tablo 3. Lisansüstü eğitimden beklentiler

\begin{tabular}{lll}
\hline Tema $\mathbf{( N = 2 6 )}$ & Frekans (f) & Oran $\mathbf{( \% )}$ \\
\hline Bilgi ve becerilerini artırmak & 19 & 61,3 \\
\hline Araştırma ve çalışmayı teşvik etmesi & 5 & 16,1 \\
\hline Akademisyenlere yönelik beklentiler & 4 & 12,9 \\
\hline Beklentisiz & 3 & 9,7 \\
\hline
\end{tabular}

Lisansüstü eğitim alan öğrenciler büyük oranda (f=19,\%61,3), aldıkları eğitimin bilgi ve becerilerini artıracağını düşünmektedirler. Bu yönde görüş bildiren öğrenciler bu beklentilerini şu şekilde ifade etmişlerdir:

"Eğitim yönetimini profesyonel kişilere emanet edilmesi gerektiğini düşündüğ̈̈m için donanımlı bir yöneticinin sahip olması gereken özelliklere ilişkin bilgi almak....." (TL2).

"Eğitime başlamadan önce eğitimden beklentim kendimi yöneticilik alanında geliştirecek bilgi ve beceriyi kazanmak" (TL5).

"Beni yenilemesi ve okuluma faydal olacak bir konuma getirebilmesi" (TS5).

Aldıkları eğitimin araştırma ve çalışmayı teşvik etmesi ( $\mathrm{f}=5, \% 16,1)$ gerektiğini düşünen öğrencilerin görüşleri de şöyledir:

“...... sorunlara çağdaş çözümler üretebilmek ve bir konu hakkında bilimsel araştırma yapabilmek." (TL1).

“..... Ayrıca beni çalışmaya teşvik eden bir ortam olması da beklentilerimin arasindaydı" (D5).

"Alana ve uygulamaya katkı yapacak özgün fikirler geliştirilmesine olanak verecek bilimsel bilgiyi üretebilmek" (D6).

Lisansüstü eğitim alan öğrencilerin dikkat çeken beklentilerinden birisi de akademisyenlere yönelik beklentileridir ( $\mathrm{f}=4, \% 12,9)$. Bu yöndeki beklentiler şunlardır: 
"Lisansüstü eğitime başlamadan önce beklentim derslerimizi aldığımız akademisyenlerin bize bilgilerini aktardıkları alanda teoriden çok pratik bilgiye de sahip olmalarıdıd" (TL13).

“..... Deneyimli akademisyenlerin fikirlerinden istifade edebilme....." (D2).

"Akademisyenlerin bilgilerinden faydalanarak çalışmalarımızda uygulamaya geçirmeye çalışmak" (TS1).

Lisansüstü eğitim alan öğrencilerden aldıkları eğitimden herhangi bir beklentisi olmayanların ( $\mathrm{f}=3, \% 9,7)$ görüşleri de şöyledir:

"Daha çok formalite bir eğitim olacağını düşünmekteydim. Yani sadece sınavlara girip çıkacağımızı, basit çabalarla eğitimin gerçekleşeceğini düşünüyordum" (TL8).

"Ĕgitim fakültesi mezunu olduğum için derslerin işlenişi, dersleri aşağı yukarı tahmin ediyordum ama fazla bir beklenti içinde değildim zaten" (TS3).

\section{Beklentilerin Karşılanma Durumuna İlişkin Bulgular}

$\mathrm{Bu}$ soruya cevap verenler genellikle beklentilerim karşılandı, karşılanmadı ya da orta düzeyde karşılandı şeklinde cevap vermişlerdir. Tablo 4'te, bu cevaplara ilişkin frekans ve yüzde değerleri verilmiştir.

Tablo 4. Beklentilerin karşılanma düzeyine ilişkin sonuçlar

\begin{tabular}{lll}
\hline & Frekans (f) & Oran (\%) \\
\hline Karşılandı & 16 & 61,54 \\
\hline Orta düzeyde karşılandı & 8 & 30,76 \\
\hline Karşılanmadı & 1 & 3,85 \\
\hline Cevap Vermeyen & 1 & 3,85 \\
\hline
\end{tabular}

Tablo 4'te görüldüğü üzere, lisansüstü eğitim alan öğrencilerin büyük bir çoğunluğu (f=16, \%61,54) aldıkları eğitimin beklentilerini karşıladığını söylemişlerdir. Bu yönde cevap veren öğrenciler, fikirlerini şöyle beyan etmişlerdir:

"Lisansüstü eğitim almakta olduğum 3 aylık süreç içerisinde beklentilerime büyük ölçüde cevap aldiğımı görebiliyorum. Özellikle bulunduğum kurumda olaylara artık daha farkh bir gözle bakmaya başladığımı hissettim" (TL11).

"Beklentilerimin fazlasıyla karşılandığını söyleyebilirim. Aynı bölümde başka üniversitelerde eğitim gören öğrencilere göre 
doyumum fazla diyebilirim. Ayrıca şimdiye kadar aldığım eğitim farklı düşünmemi sağladı" (TL12).

"5 üzerinden değerlendirirsem sonuç 5'tir. Üniversitemin, enstitümün öğretim görevlileri bence kaliteli, ufku açı, araştırmaya çok önem veren,......, nitelikli olduklarm yaşayarak gördüm. .......... lisans eğitiminden sonra bu ĕgitim beklentilerimi karşıladı." (TS2).

"Beklentilerimi karşılayacak düzeyde bir eğitim aldı̆̆̆mı düşünüyorum. Eğitim aldığım lisansüstü programin beklentilerimden çok daha fazla bana katkısı olduğunu söyleyebilirim"(D1).

Bazı öğrenciler $(\mathrm{f}=8, \% 30,76)$, beklentilerinin orta düzeyde karşılandığını belirtmişlerdir. Bu öğrencilerin beklenti düzeylerinin orta düzeye düşmesi genellikle derslerin daha çok teorik olması ve uygulamadan hayata geçirilememesi, kaynak sıkıntısı ve akademisyenlerin öğrencilerden beklentilerinin yüksek olmasından kaynaklanmaktadır. Bunu belirtirken kullandıkları ifadeler şunlardır:

"Orta. Yapmamız istenen çoğu çalışmanın dönütü etkin verilmiyor. Bazı dersler de teoriden öteye geçemiyor. Uygulamaya yönelik çalışmalar yapılmıyor. Bazı derslerde kaynak sıkıntısı çekiyoruz. Konu olarak yabancı olduğumuz bu bölümde hocalarm beklentisi çok yüksek" (TL3).

“..... özellikle iki dersin benim için faydalı olduğunu düşünüyorum. Ama bazı dersler gerçekten çok boş geçti. Bazı derslerde ise öğrendiğimiz konular meslek yaşamımızda kullanacağımız türden bilgiler olmaması bakımından beklentilerimin karşılanmadığını düşünüyorum. Sonuç olarak beklentilerimin \%50'sinin karşılandığını söyleyebilirim" (TS6).

“Bunu 1,2,3,4,5 şeklinde düşündükten sonra puan verirsem 3'ü seçerdim. Orta düzeyde diyebilirim. Çünkü bir doktora öğrencisi olarak özerk araştırma yapabilme donanımım henüz tamamlanmış değil"(D4).

Bir öğrenci de $(\mathrm{f}=1, \% 3,85)$ beklentilerinin karşılanmadığını, “...... bazı derslerin beklentilerimi karşılamadığını gördüm. Özellikle kuramsal konular çok havada kalmakta ve örnek olaylara pek yer verilmemektedir" (TL1) şeklinde ifade etmiştir. 


\section{Verilen Eğitime İlişkin Öneriler}

Verilen eğitime ilişkin öneriler, dersin işlenişine yönelik öneriler, akademisyenlere öneriler, yasal öneriler, yönetime yönelik öneriler şeklinde dört temaya ayrılmıştır. Bu temaların dağılımı Tablo 5'te verilmiştir.

Tablo 5. Lisansüstü eğitim hakkında öneriler

\begin{tabular}{lll}
\hline & Frekans (f) & Oran (\%) \\
\hline Dersin işlenişine yönelik öneriler & 11 & 36,7 \\
\hline Akademisyenlere öneriler & 7 & 23,3 \\
\hline Yasal öneriler & 5 & 16,7 \\
\hline Yönetime yönelik öneriler & 4 & 13,3 \\
\hline Cevap vermeyen & 2 & 6,7 \\
\hline Öneride bulunmayan & 1 & 3,3 \\
\hline
\end{tabular}

Lisansüstü eğitim alan öğrenciler en çok derslerin işlenmesine yönelik öneriler ( $\mathrm{f}=11, \% 36,7)$ getirmişlerdir. Bu konuda görüş belirten öğrenciler şunları söylemişlerdir:

"Teorik içeriğin oranı azaltılarak daha çok örnek olay ve sunu yapmanın ötesine giderek, aktif katılacağımız sahada araştırma ve uygulamalar yapılabilir. Hatta ögretmenlikte yapılan okullarda staj uygulamasinin yönetim ve denetim alanlarinda da yapılması..." (TL2).

"Derslerde teorik konularm örnek olay incelemeleriyle geliştirilmesi ve durum analizleriyle desteklenmesi sağlanabilir. ...... eğitim sirasında veya eğitim sonrasinda staj gibi okullarda idari görevlere alınarak öğrendiklerini uygulama imkânları kazanmaları sağlanabilir" (TL5).

"Özellikle araştırmalarla ilgili çalışmalarda, bir örnek araştırma üzerinde birlikte çalışı yöntemler kavratılabilir" (TS1).

"Teorik olarak öğrendiklerimizi daha iyi kavrayabilmek için, üniversitenin ayarlamasıyla, müfettişlerle birlikte teftişe giderek onları gözlemlemek" (D2).

Öğrencilerin bir kısmı da akademisyenlerin derslerin işlenmesi esnasındaki tutumları, ödevler gibi konularda önerilerde bulunmuşlardır. Ayrıca danışmanlarla olan ilişkilerin daha aktif olması ve akademisyenlerin kaynak bulma konusunda destekte bulunması gerektiği şeklinde görüş belirtmişlerdir. Bazı öğrencilerin bu öneriler hakkındaki ifadeleri şunlardır:

"Yapılan çalışmaların bizlere sunulması, verilen ödevlerin hangi ölçülerde derecelendirileceğinin gösterilmesi, yaptı̆̆ımız araştırma 
ve ödevlerin amaçlarmın net olarak ifade edilmesi, bu alanda kaynak sıkıntısı yaşadığımızı akademisyenlerin anlaması ve bu konuda destek olmasi" (TL3).

"....... Ancak başka kurumlarda çalıştı̆̆ımız unutulduğundan ağır ödevler altında ezilmekteyim. Bu konuda biraz daha anlayışl olunması gerekmektedir. Derslerin anlatılması konusunda eksiklikler görmekteyim. ........ öğrenmeye ihtiyacımız yokmuş, araştırmayı öğrensek yetermiş gibi bir ders işleyiş tarzı geliştirilmiş durumdadır. ....... Sadece bir hocamız hedeften haberdar edip dersin sonunda sizden bunlar bekliyorum gibi bir açıklama yaptı. ..... akademisyenlerin bize daha çok rehber olmalari, hedeften haberdar etmeleri, daha az ve anlaml ödevler vererek desteklemeleri beni daha başarll bir öğrenci yapardı" (TL10).

"Akademisyenlerin biraz daha öğrenci psikolojisini anlayarak ve yapıcı bir şekilde ders anlatmaları faydah olurdu" (TS5).

"Danışman öğrenci iletişimi daha fazla olabilir, ....... yurt içi ve yurt dışı kongre ve sempozyumlara katılım teşvik edilebilir." (D1).

"Danışman olarak seçilen hocaların öğrencilerle haftada bir, ders formatında görüşmesi ve yardımda bulunması"(D2).

Öğrenciler özellikle Milli Eğitim Bakanlığı yönetici seçimlerinde "Eğitim Yönetimi" lisansüstü eğitim almış kişilerin öncelikli olması gerektiğini düşünmektedirler. Ayrıca lisansüstü eğitim için belirli bir miktar para harcanmak zorunda kalmasından dolayı maddi destek verilmesi de önerilmiştir. Bu öneriler üniversiteden ziyade yasal olarak yerine getirilmesi gereken ifadelerdir. Bu konuda belirtilen görüşlerden bazıları şunlardır:

“..... bu eğitimin okul yöneticilerine zorunlu olması gerektiği, öğretmenlerin de bu eğitimi almaya teşvik edilmesi gerektiğgi kanaatindeyim" (TL6).

"Üniversitede lisansüstü eğitim alan öğrenciler için hem konaklama hem de istihdamin artırlmasl, ekonomik kaygılarmın giderilmesi ile eğitim alan öğrencilerin tüm zamanlarmı üniversitelerde geçirmesi ile eğitimin daha ileriye taşınacağı kanaatindeyim" (TL7).

“..... Bölümden mezun olanlarm eğitim yöneticisi olarak eğitim kurumlarmda yönetici kadrolarna alınma kriterlerinde olmast gerekir" (TL12).

“..... Önce ülkemizdeki eğitim sistemi kökten değgiştirilip düzenli hale getirilmeli" (TS3). 
"Doktora düzeyinde eğitimin tam zamanlı olması gerektiğini düşünüyorum. Fakat bu olasıllk benim koşullarımdan dolayı olasıllk dişı..... bakanlık bu konuda bir şeyler yapabilir" (D6).

Bazı öğrenciler ( $\mathrm{f}=4, \% 13,3)$, bölüm ya da enstitünün yapabileceği öneriler sunmuşlardır. Bunlar bağımsız kütüphane, diğer üniversitelerdeki akademisyenlerle iletişim gibi önerilerdir. Bu önerileri şu şekilde ifade etmişlerdir:

“..... eğitim yöneticilerinin deneyimlerinden yararlanabilmemiz için yapılacak seminerler ya da söyleşilerin faydal olabileceğgini düşünmekteyim" (TL4).

"Enstitü binasının ayri olması, enstitü kütüphanemizin oluşturulması önerilerim arasında" (TS2).

"...... Sinav olmamal, not için gelinmemeli. Akademisyenler ve öğrenciler sınav kaygısı duymamalı. Ders programı oluşturulurken ilçelerden gelenler düşünülerek yapılmalı" (TS4).

"Doktora eğitimi süresince diğer üniversitelerdeki akademisyenlerle etkileşimin artması öğrenci motivasyonunu olumlu yönde etkileyebilir" (D3).

İki öğrenci $(\mathrm{f}=2, \% 6,7)$ bu soruya cevap vermezken, bir öğrenci de $(\mathrm{f}=1, \% 3,3)$ yapılması gerekenlerin yapıldı ğını söylemiştir. Bunu şu şekilde ifade etmiştir:

"Yapılacakların yapıldığını düşünüyorum. Çünkü diğer üniversitelerden bazılarında da araştırmalar yaptım ve eğitim yönünden çok iyi yönde eleştirilerle karşılaştım" (TL4).

\section{Tartışma, Sonuç ve Öneriler}

Lisansüstü eğitim alan öğrencilerin büyük çoğunluğu eğitime kendini geliştirmek amacıyla başlamıştır. Lisansüstü eğitime başlarken akademik kariyer yapmak ve Milli Eğitim Bakanlığı bünyesinde yönetici olmak da bu eğitime başlayanların amaçları arasındadır. Bu bulgu, Oluk ve Çolak'ın (2005) öğretmen olarak çalışan lisansüstü öğrencilerinin karşılaştıkları sorunları inceledikleri araştırmalarındaki bulgularıyla örtüşmektedir. Çalışmada lisansüstü eğitime devam eden öğretmenlerin akademik kariyer ve meslek bilgi kazanmayı amaçladıkları sonucuna ulaşılmıştır. Sayan ve Aksu (2005), lisansüstü eğitim yapan akademik personel dışındaki bireylerin lisansüstü eğitim yapmadaki amaçlarının özellikle kendilerini alanlarında yetiştirmek, akademisyen olabilmek ve meslekte yükselmek olduğunu bulmuşlardır. Başer, Narlı ve Gürhan (2005), 
lisansüstü eğitime devam eden öğretmenlerin kendilerini geliştirmek, atanma ve akademik kariyer amacıyla lisansüstü çalışma yaptıkları sonucuna ulaşmışlardır. Savaş ve Topak (2005), lisansüstü öğrenim gören öğrencilerin beklentilerinin yeni bilgiler elde etmenin mutluluğunu yaşamak, akademik kariyer elde etmek, kendini gerçekleştirme fırsatını kazanmak olduğunu bulmuşlardır. Arı, Pehlivanlar ve Çömek (2005), lisansüstü eğitim öğrencilerinin gördükleri eğitim hakkındaki beklentileri konusunda alan bilgisi ve kariyer cevabına ulaşmışlardır. Ören, Yılmaz ve Güçlü (2012)'nün çalışmalarında öğretmen adaylarının lisansüstü eğitime yönelik görüşleri incelenmiştir. Araştırmanın bulgularına göre, lisansüstü eğitim almak isteyen öğretmen adayları kendilerini geliştirmek, alanlarında uzmanlaşmak, kariyer ve akademik personel olmak amaçlarıyla bu eğitime başlayabileceklerini söylemişlerdir. Alabaş, Kamer ve Polat (2012), öğretmenlerin öncelikle kariyer gelişimi için lisansüstü eğitime başladıkları sonucuna ulaşmışlardır.

Öğrencilerin lisansüstü eğitimden bilgi ve becerilerini artırması, araştırma ve çalışmayı desteklemesi, akademisyenlerin alanlarında uzman olması gibi beklentileri vardır. Araştırma bulguları, genellikle bu beklentilerin karşılandığı görüşü yansıtmaktadır. Alabaş, Kamer ve Polat'ın (2012) çalışmalarında öğretmenler, alanlarında ileri düzey bilgi sahibi olma beklentisi içinde olduklarını söylemişlerdir.

Lisansüstü eğitimin geliştirilmesi konusunda genellikle derslerin işlenişine yönelik öneriler getirilmiştir. Burada da en fazla getirilen öneri derslerde teorik bilgiler yerine uygulama ve tartışmalara yer verilmesidir. Ayrıca lisansüstü eğitim ile iş hayatının bir arada yürütülmesinin güçlüğü nedeniyle, lisansüstü eğitim alanlara yönelik çalışma yapılması, akademisyenlerin bunları göz önünde bulundurarak ödev vermesi, lisansüstü eğitim alanlara ekonomik destek sağlanması gerektiği belirtilmiştir. Sayan ve Aksu (2005), akademik personel dişında lisansüstü eğitim yapan öğrencilerin ekonomik açıdan zorlandıklarını belirtmiş; lisansüstü eğitim yapanlara devletin burs vermesini, çalışarak lisansüstü eğitim alanlara da ücretli izin verilmesini önermişlerdir.

Bu çalışma belirli bir bilim dalına yönelik olması, sadece Pamukkale Üniversitesi öğrencilerinin görüşlerine yer verilmesi gibi sınırlılıklara sahiptir. Bu sınırlılıklar da göz önünde bulundurularak aşağıdaki öneriler getirilmiştir:

- Bu çalışma Pamukkale Üniversitesi EYDPE bilim dalında eğitim alan öğrencilerin görüşleri üzerine yapılmıştır. Diğer bölümler ve üniversitelerde de böyle çalışma yapılabilir. 
- Açık uçlu sorulara verilen cevaplar doğrultusunda bir ölçek hazırlanabilir.

- Hazırlanan ölçek ile daha geniş bir örneklem grubuna yönelik nicel bir çalışma yapılabilir. Bu çalışma ile cinsiyet, eğitim programı, üniversite gibi değişkenlere göre farklılık gösterip göstermediği incelenebilir.

- Hem öğrenim görüp hem de çalışan lisansüstü öğrencilerinin dersler ve ödevler konusunda önerileri olmuştur. Bu öneriler doğrultusunda eğitim programları yeniden gözden geçirilmelidir.

- Lisansüstü eğitimi cazip hale getirecek düzenlemeler yapılmalıdır. Bu konuda üniversiteler ve siyasi irade ortak çalışma içerisine girebilir.

\section{Kaynakça}

Alabaş, R., Kamer, S. T. ve Polat, Ü. (2012). Öğretmenlerin kariyer gelişimlerinde lisansüstü eğitim: tercih sebepleri ve süreçte karşılaştıkları sorunlar. E-international Journal of Educational Research, 3(4), 89-107.

Alhas, A. (2006). Lisansüstü eğitim yapmakta olan milli eğitim bakanliğı öğretmenlerinin lisansüstü eğitime bakış açıları. Yayımlanmamış yüksek lisans tezi. Gazi Üniversitesi Eğitim Bilimleri Enstitüsü, Ankara.

Arı, E., Pehlivanlar, E. ve Çömek, A. (2005). Lisansüstü eğitimi öğrencilerinin gördükleri eğitim hakkındaki beklentileri ve görüşlerinin belirlenmesi. Dokuz Eylül Üniversitesi Buca Eğitim Fakültesi Dergisi (Özel Sayl- 1): Lisansüstü Ĕ̆itim, 17, 231- 235.

Başer, N., Günhan, B. ve Güneş, Y. (2005). Ortaöğretim fen ve matematik alanında öğrenim gören tezsiz yüksek lisans öğrencilerin aldıkları eğitimden beklentileri, yaşadıkları sorunlar ve çözüm önerileri. Dokuz Eylül Üniversitesi Buca Eğitim Fakültesi Dergisi (Özel Sayı- 1): Lisansüstü Eğitim, 17, 95-101.

Christensen, L. B., Johnson, R. B. \& Turner, L., A. (2015). Araştırma yöntemleri desen ve analiz (Çev. Ed. Ahmet Aypay). Ankara: Anı Yayıncılık.

Ekiz, D. (2009). Bilimsel Araştırma Yöntemleri. Ankara: Anı Yayıncılık.

Karakütük, K. (2002). Öğretim üyesi ve bilim insanı yetiştirme-lisansüstü öğretimin planlanması (5. Baskı). Ankara: Anı Yayıncılık.

Kaya, S., Sezgin, G. ve Kavcar, N. (2005). Eğitim bilimleri enstitüsünde lisansüstü eğitimin öğrenci ve öğretim üyesi açısından 
değerlendirilmesi. Dokuz Eylül Üniversitesi Buca Eğitim Fakültesi Dergisi (Özel Sayı- 1): Lisansüstü Ĕ̆itim, 17, 321- 326.

MEB'na Bağlı Eğitim Kurumları Yöneticilerinin Görevlendirilmelerine İlişkin Yönetmelik. (2015). T.C. Resmi Gazete, 29494, 06/10/2015.

Oluk, S., Çolak, F.(2005). Milli Eğitim Bakanlığı'na bağlı okullarda öğretmen olarak çalışan lisansüstü öğrencilerinin karşılaştıkları bazı sorunlar. Dokuz Eylül Üniversitesi Buca Eğitim Fakültesi Dergisi (Özel Sayı- 1): Lisansüstü Eğitim, 17, 141- 144.

Ören, F. Ş.., Yılmaz, T. ve Güçlü, M. (2012). Öğretmen adaylarının lisansüstü eğitime yönelik görüşlerinin analizi. Eğitim ve Öğretim Araştırmaları Dergisi, 1(2), 189- 201.

Pamukkale Üniversitesi Lisansüstü Eğitim ve Öğretim Yönetmeliği (2015). T.C. Resmi Gazete, 29411, 09/07/2015.

Savaş, B., Topak, E.(2005). Lisansüstü öğrenim gören öğrencilerin beklentileri ve lisansüstü öğrenimi talep etme gerekçeleri. Dokuz Eylül Üniversitesi Buca Ĕ̆itim Fakültesi Dergisi (Özel Sayl- 1): Lisansüstü Eğitim, 17, 145- 154.

Sayan, Y., Aksu, H. H. (2005). Akademik personel olmadan lisansüstü eğitim yapan bireylerin karşılaştıkları sorunlar üzerine nitel bir çalışma: Dokuz Eylül Üniversitesi-Balıkesir Üniversitesi durum belirlemesi. Dokuz Eylül Üniversitesi Buca Eğitim Fakültesi Dergisi (Özel Sayı- 1): Lisansüstü Ĕ̆itim, 17, 59-66.

Sevinç, B. (2001). Türkiye'de lisansüstü eğitim uygulamaları, sorunlar ve öneriler. Ankara Üniversitesi Eğitim Bilimleri Fakültesi Dergisi, 34(1), 125137.

Ünal, Ç. ve İlter, İ. (2010). Sınıf öğretmeni adaylarının lisansüstü eğitime olan tutumları (Fırat, Erzincan ve İnönü Üniversitesi sınıf öğretmenliği ABD örneği). Atatürk Üniversitesi Sosyal Bilimler Enstitüsü Dergisi, 14 (2), 1-18.

Varış, F. (1972). Türkiye'de lisansüstü eğitim (pozitif bilimlerin temel ve uygulamalı alanlarda). Ankara Üniversitesi Eğitim Bilimleri Fakültesi Dergisi, 5(1), 51-74.

Yıldırım, A. ve Şimşek, H. (2011). Sosyal bilimlerde nitel araştırma yöntemleri. (8. Baskı). Ankara: Seçkin Yayıncılık. 
\begin{tabular}{l|l} 
Ü. KAHRAMAN, T. N. TOK & 164
\end{tabular} 